access to such a wide expanse of the former Soviet Union in the years before the cultural exchange program was established.

Warren's scholarly contributions include, above all, Karl Radek, the Last Internationalist (1970), which remains the definitive study of this leading Bolshevik, and his edited volume The Development of Soviet Foreign Policy: Studies in Honor of W. W. Kulski (1973), which contributed to the establishment of this field of study among historians of the Soviet Union. In recent years, Warren was at work on a large study of the Jewish community in Bialystok. He also published in fields beyond his specialization in Soviet history, best represented by his book, A History of Socialism and Communism in Modern Times: Theorists, Activists, and Humanists (1982), which has gone through three editions. As clearly evidenced in the comprehensive notes to these volumes, he had a reading knowledge of Polish, German, and Yiddish as well as Russian. In recognition of these achievements, he was awarded the senior scholar award at the annual meeting of the Southern Conference of Slavic Studies in 2004.

Warren's reputation at Duke among both his many graduate students and the literally thousands of undergraduates who filled auditorium-size classrooms to take his courses, was virtually legendary. He had the gift of precise timing in his lectures, always knowing when to interject his subtle humor into the huge array of factual material and analysis. $\mathrm{He}$ combined this with the ability to share his enthusiasm for the subject matter with his students in a way that few academics have mastered. For all of us who had the good fortune to have had personal and professional contacts with Warren over the years, his moral integrity and high professionalism will remain a standard to emulate.

Martin A. Miller

Duke University

February 2008

\title{
John Doyle Klier, 1944-2007
}

"I count myself a wannabe Mercurian (qualifications: ex-Catholic, ex-German-Irishethnic, ex-American from Rust Belt US) who currently resides in London teaching Jewish history - that most slippery and disputatious of slippery and disputatious 'disciplines' - to the elite sons and daughters of Mercurians who long to be British (and therefore Apollonians)." This is the ironic characterization that John Klier gave himself and his occupation in 2005.

His road to this strange and fascination occupation took the following form. John's interest in the Soviet Union (and subsequently in the history of the Russian empire) rose from such varying events as the repression of the 1956 Hungarian uprising and Iurii Gagarin's flight into space. Born in Bellefonte, Pennsylvania, on 13 December 1944, John took his BA and MA at the University of Notre Dame in Indiana and completed his doctorate in 1975 at the University of Illinois, Urbana-Champaign. His doctoral dissertation concerned the origin of the "Jewish question" in Russia. Subsequently, in answer to the traditional question of what brought him to the study of Jewish history, John would answer, "I knew I would never be bored."

John taught for many years at Fort Hays State University in Hays, Kansas, which he called a "Medvezhii ugol Ameriki" (roughly, "a god-forsaken corner of America"). But there was a bright side: as John put it, "it was easy to work there without getting distracted by anything. There was one movie theater and two TV channels. It was already possible to get the Jewish press on microfilm. I taught days, and continued my research in the evenings. I read Rassvet, Sion, Den', Voskhod."

Serious work on the history of Russia's Jews was possible only if one could gain access to Soviet libraries and archives. But the topic of Jews was absolutely a "no go" for scientific exchanges with the USSR. John had to think of a topic that, on the one hand, allowed him access to exactly those materials he needed, and, on the other hand, was free of the adjective Jewish: the topic he chose was the Russian press. In a period of extreme suspicion toward foreigners, he was able to spend two years in Leningrad (1977-78 and 
1980-81), working mainly in the newspaper hall of the renowned Saltykovka (the public library). At the beginning of the 1990s, John became one of the first western historians to plunge into the exploration of the archives of the former USSR that were newly opened for researchers.

From 1990 on, John worked at University College, London. Having begun as a lecturer in 1990, he was appointed Sidney and Elizabeth Corob Professor of Modern Jewish History in 1996 and was the head of the Department of Hebrew and Jewish Studies for much of the 1990s. For a number of years, he edited the journal East European Jewish Affairs.

In the words of Antony Polonsky, John "was one of a group of historians who, in the last thirty years, transformed our understanding of the history of the Jews of the tsarist empire." John examined the Jewish question in the context of the history of the Russian empire. In his research, he undertook to "rehabilitate" Russian power to a certain extent, demonstrating that its politics in relation to the Jews could be explained as much by the ideas of the European Enlightenment as by religious intolerance rooted in the Byzantine heritage. He convincingly demonstrated this in his first book, Russia Gathers Her Jews: The Origins of the "Jewish Question" in Russia, 1772-1825 (1986), in which he examined the politics of Catherine II, Paul I, and Alexander I in relation to their new subjects. In 2000, a Russian translation of this book was released-Rossiia sobiraet svoikh evreev: Proiskhozhdenie evreiskogo voprosa $v$ Rossii: 1772-1825. This was one of those rare instances when the translation is better than the original. Archival sources were used in the Russian publication, while the original research was based primarily on published sources.

In the monograph Imperial Russia's Jewish Question, 1855-1881 (1995), the subject of research was primarily Russian society's relationship to the "Jewish question." John convincingly demonstrates that despite the apparent all-powerfulness of the Russian emperors, they heeded public opinion. Indeed, Russian society, not wishing to make peace with the "domination" of the Jews, served not infrequently to restrict the propagation of reform aiming to emancipate the Jews. Russian bureaucracy was also a part of Russian society, however, and antisemitism was widespread in its midst (though enlightened bureaucrats understood the abnormalities of the position of the Jews and the necessity, in the end, of their equalization in law).

The chronological-and logical-continuation of his research was to be a book on the Jewish pogroms in Russia during the early 1880s. An important milestone in John's work on the topic of pogroms was the collection Pogroms: Anti-Jewish Violence in Modern Jewish History (1992), which he jointly edited with Shlomo Lambroza. John dedicated a series of articles and papers to the topic of anti-Jewish forces, and he found my nickname for him, "chief pogromchik," highly amusing. The result of his many years of work is the forthcoming monograph (to be published by Cambridge University Press), Southern Storms: Russians, Jews and the Crisis of 1881-1882, the release of which, alas, he did not live to see.

John was also the coauthor, with his wife, Helen Mingay, of the popular book, although based on primary sources, The Search for Anastasia: Solving the Riddle of the Lost Romanous (1995).

Russia was for John not just the object of research or a place in which the archives and libraries in which he was interested were located. He had a multitude of friends here, and, for us, his colleagues, his home in the London suburbs was always open. He was a member of the Academic Council of the International Center for Russian and East European Jewish Studies in Moscow. John was not an "honorary" member of the council. He took a most active part in the work of the center, and he was the driving force behind the conference "Anti-Jewish Violence: Reconceptualizing 'the Pogrom' in European History, Seventeenth to Twentieth Centuries" held in Stockholm in May 2005 and organized by the center, together with Hebrew University of Jerusalem and Södertörn University College in Stockholm. The collection of articles based on the conference materials was evidently the last book on which John was working. The manuscript was still on his computer, and I did not have a chance to answer his questions about my article.

John was a devoted participant in the yearly conferences organized by the center, and he was to have attended the conference held in December 2007. On 11 September 2007 , he wrote that he needed immediate hospitalization and begged forgiveness for being unable to participate in the upcoming conference. At such a time he was able to think of that. 
He died in London, England, on 23 September 2007. On 24 September the awful news of his death reached me. It is not possible to imagine the study of the history of Russian Jews without his labors. Although some of his plans are not now fated to come to fruition, the books and articles he left behind remain the inheritance of today's and subsequent generations of researchers and students. His memory will remain forever in the hearts of those who knew him. Farewell, John.

\author{
Oleg Budnitski I \\ Institute of Russian History, \\ Russian Academy of Sciences, and \\ International Center for Russian and \\ East European Jewish Studies, Moscow \\ March 2007 \\ translated by Jesse D. Murray
}

